\title{
Karakteristik Kasus Kematian dengan Temuan Cedera Kepala Januari 2018 - Desember 2019
}

\author{
Muhammad Tsani Mudzakir ${ }^{1}$, Rika Susantí, Noverial ${ }^{\beta}$ \\ ${ }^{1}$ Fakultas Kedokteran Universitas Andalas, Padang \\ ${ }^{2}$ Bagian Forensik Fakultas Kedokteran Universitas Andalas, Padang \\ ${ }^{3}$ Bagian Bedah Fakultas Kedokteran Universitas Andalas, Padang
}

\begin{abstract}
A B S T R A C T
Latar Belakang. Cedera kepala masih menjadi penyebab utama morbiditas dan mortalitas pada populasi dunia berumur dibawah 45 tahun. Kejadian cedera kepala di seluruh dunia cenderung untuk terus meningkat.

Objektif. Untuk mengetahui karakteristik kematian dengan temuan cedera kepala di Rumah Sakit Umum Pendidikan Dr. M. Djamil Padang tahun 2018 - 2019.

Metode. Penelitian deskriptif retrospektif dengan desain cross

accidents (88.4\%). Most of the deaths occurred in the hospital (89.3\%). Most types of wounds are abrasions $(90,1)$.

Conclusion. The case of death with the most head injury findings is male, in the age group 18 to 65 years. The job category with most cases is students. The most common cause of head injuries in traffic accidents. Most deaths occurred in hospitals. Most types of wounds are abrasions.

Keyword: Head injury
\end{abstract} sectional menggunakan data sekunder terhadap 121 kasus kematian dengan temuan cedera kepala, dengan teknik total sampling.

Hasil. Didapatkan 121 kasus kematian dengan temuan cedera kepala yang memenuhi kriteria inklusi. Jenis kelamin terbanyak adalah laki-laki (72,7\%), pada kelompok usia 18 hingga 65 tahun $(62,8 \%)$. Kategori pekerjaan terbanyak adalah pelajar $(26,5 \%)$. Penyebab paling umum dari cedera kepala adalah kecelakaan lalulintas $(88,4 \%)$. Lokasi kematian terbanyak terjadi di rumah sakit $(89,3 \%)$. Jenis luka terbanyak adalah luka lecet $(90,1 \%)$.

Kesimpulan. Kasus kematian dengan temuan cedera kepala terbanyak Jenis kelamin laki-laki, pada kelompok usia 18 hingga 65 tahun. Kategori pekerjaan dengan kasus terbanyak adalah pelajar. Penyebab paling umum dari cedera kepala adalah kecelakaan lalulintas. Lokasi kematian terbanyak terjadi di rumah sakit. Jenis luka terbanyak adalah luka lecet.

Kata kunci: cedera kepala

Background. Head injury is still a major cause of morbidity and mortality in the world population under 45 years of age. The incidence of head injuries worldwide tends to continue to increase.

Objective. To determine the characteristics of death with head injury findings in Dr. General Hospital of Education. M. Djamil Padang in 2018-2019.

Method. A retrospective descriptive study with a crosssectional design using secondary data on 121 cases of death with a head injury, using a total sampling technique.

Result. There were 121 cases of death with head injury findings that met the inclusion criteria. Most of the sex is male (72.7\%), especially in the age group 18 to 65 years (62.8\%). The occupational category with the most cases was students (26.5\%). The most common cause of head injury was traffic

\section{Apa yang sudah diketahui tentang topik ini?}

Cedera kepala masih menjadi penyebab utama morbiditas dan mortalitas pada populasi dunia berumur dibawah 45 tahun. Kejadian cedera kepala di seluruh dunia cenderung untuk terus meningkat.

\section{Apa yang ditambahkan pada studi ini?}

Terdapat 121 kasus kematian dengan temuan cedera kepala dan yang terbanyak pada Jenis kelamin laki-laki, pada kelompok usia 18 hingga 65 tahun. Kategori pekerjaan dengan kasus terbanyak adalah pelajar. Penyebab paling umum dari cedera kepala adalah kecelakaan lalulintas. Lokasi kematian terbanyak terjadi di rumah sakit. Jenis luka terbanyak adalah luka lecet.

\section{CORRESPONDING AUTHOR}

Name: Muhammad Tsani Mudzakir

Phone: +6282197221404

E-mail: sanimuzakir@gmail.com

\section{ARTICLE INFORMATION}

Received: September $23^{\text {rd }}$, 2020

Revised: October $15^{\text {th }}, 2020$

Available online: October $31^{\text {st }}$, 2020 


\section{Pendahuluan}

Menurut laporan World Health Organization (WHO), sekitar 1,2 juta orang meninggal dengan diagnosis cedera kepala setiap tahunnya yang diakibatkan oleh KLL dan jutaan lainnya terluka atau cacat. Sebagian besar kematian seharusnya dapat dicegah. di negara-negara dengan penghasilan rendah dan menengah, terdapat banyak pengguna kendaraan roda dua, terutama pengguna sepeda motor, dan lebih dari 50\% terluka atau meninggal akibat KLL. ${ }^{1}$

Cedera kepala masih menjadi penyebab utama morbiditas dan mortalitas pada populasi dunia berumur dibawah 45 tahun. $^{2}$ Kejadian cedera kepala di seluruh dunia cenderung untuk terus meningkat. Hal ini berhubungan dengan meningkatnya penggunaan kendaraan bermotor yang terlihat jelas pada negara-negara yang memiliki pendapatan rendah dan menengah. ${ }^{1}$

Menurut sebuah penelitian yang dilakukan di Black Lion Specialized Hospital di Ethiopia pada Oktober hingga Agustus 2015 terdapat 390 pasien datang dengan cedera kepala,dengan rincian 335 pria $(85,9 \%)$ dan 55 wanita $(14,1 \%) .^{2}$

Laki-laki memiliki risiko lebih tinggi untuk terkena cedera kepala dibandingkan perempuan. Rasio jenis kelamin berbeda-beda di setiap negara, 1,18:1 di Finlandia Tenggara dan 4,81:1 di Afrika Selatan. Usia paling banyak terkena cedera kepala berkisar antara 29-45 tahun. Negara dengan angka kejadian cedera kepala tertinggi adalah Selandia Baru dengan 811/100.000 per tahun, sedangkan yang terendah adalah Eropa Barat dengan 7,3/100.000 per tahun. Berdasarkan data yang telah dikumpulkan diberbagai negara dengan kejadian cedera kepala dari rendah ke tinggi adalah Belgia, Swiss, Iran, Cina, Finlandia, Portugal, Australia, Norwegia, Kanada, Jerman, Italia, Perancis, Austria, Afrika Selatan, Swedia, Spanyol, Amerika Serikat dan Selandia Baru. Dengan angka kematian tertinggi pasien cedera kepala terdapat di Afrika Selatan dengan 80,73/100.000 per tahun, sedangkan yang terendah terdapat di Perancis dengan 5,2/100.000 per tahun. ${ }^{3}$

Beberapa artikel penelitian tentang epidemiologi cedera kepala telah banyak dilakukan di Eropa dan Amerika Utara. Di Asia sebagian besar negara tidak memiliki data epidemiologi cedera kepala, namun dalam beberapa tahun terakhir jumlah studi mengenai cedera kepala mulai meningkat. Di Indonesia, angka pasti dari kejadian cedera kepala sulit ditentukan karena berbagai faktor, misalnya sebagian kasus-kasus yang fatal tidak sampai ke rumah sakit, selain itu juga terdapat kasus yang ringan tidak datang ke dokter kecuali setelah timbul komplikasi. Beberapa penelitian epidemiologi cedera kepala telah dilakukan di berbagai rumah sakit. Pada tahun 2005 terdapat 434 kasus di RS Cipto Mangunkusumo, 347 kasus di RS Swasta Siloam Gleaneagles dan 125 kasus di RS Atma Jaya pada tahun 2007.4 Sebanyak 480.000 kasus per tahun diperkirakan sebagai insiden cedera kepala yang memerlukan perawatan di rumah sakit. Cedera kepala paling banyak terjadi pada laki-laki berumur antara 1524 tahun, dengan angka kejadian cedera kepala pada laki-laki $(55,4 \%)$ lebih banyak dibandingkan perempuan,hal ini diakibatkan karena mobilitas yang tinggi dikalangan usia produktif pada jenis kelamin laki-laki. ${ }^{5}$

Cedera kepala yang disebut juga dengan Traumatic Brain Injury (TBI) adalah masalah kesehatan masyarakat yang kritis di seluruh dunia, dengan beban sosial ekonomi yang signifikan. ${ }^{6}$ Meskipun peningkatan peraturan keselamatan di negara-negara berkembang telah ikut serta dalam menurunkan angka kejadian cedera kepala terkait lalu lintas, kejadian cedera kepala di negara-negara berpenghasilan rendah terus meningkat. Kenaikan dari angka kejadian ini merupakan hasil dari peningkatan urbanisasi dan motorisasi di negara-negara berpenghasilan rendah dan menengah. Terlepas dari meningkatnya jumlah TBI di negara-negara berpenghasilan rendah, sangat sedikit yang diketahui tentang epidemiologi cedera ini. ${ }^{6}$

Lapisan terluar dari kepala yaitu kulit kepala memiliki jaringan yang lunak tetapi memiliki daya lindung yang besar. Apabila tengkorak tidak dilindungi oleh kulit kepala maka hanya akan mampu menahan pukulan sebesar 40 pound/inch tetapi apabila dilindungi oleh kulit kepala maka tengkorak akan dapat menahan pukulan 425-900 pound/inch. Selain lapisan kulit, juga terdapat tulang tengkorak, yang berfungsi melindungi isi di dalamnya yaitu otak. ${ }^{7}$

Berat atau ringannya dampak patofisiologi dari trauma kepala ditentukan oleh mekanisme terjadinya cedera kepala. Cedera percepatan (akselerasi) terjadi apabila benda yang sedang 
bergerak membentur kepala yang sedang diam, sedangkan perlambatan (deselerasi) adalah apabila kepala membentur objek yang tidak bergerak. Kedua kekuatan ini bisa saja terjadi secara bersamaan apabila terdapat gerakan kepala tiba-tiba tanpa kontak langsung. Kekuatan ini bisa dikombinasikan dengan pengubahan posisi rotasi pada kepala yang menyebabkan trauma regangan dan robekan pada substansi alba dan batang otak. ${ }^{8,7}$

Data data mengenai kasus kematian dengan temuan cedera kepala yang terjadi masih sangat kurang, khususnya pada setiap daerah di Indonesia. Maka dari itu, penulis memilih Rumah Sakit Umum Pusat Dr. M. Djamil Padang yang merupakan rumah sakit tipe A dan sebagai pusat rujukan di Sumatra Barat dan sekitarnya untuk melengkapi data terkait kasus kematian dengan temuan cedera kepala. Penelitian ini untuk mengetahui karakteristik kasus kematian dengan temuan cedera kepala di Rumah Sakit Umum Pusat Dr. M. Djamil Padang periode Januari 2018 Desember 2019.

\section{Metode}

Penelitian deksriptif dengan pendekatan retrospectif dengan tujuan untuk mengetahui karakteristik kasus kematian dengan temuan cedera kepala di Rumah Sakit Umum Pusat Dr. M. Djamil padang Periode Januari 2018 sampai Desember 2019 berdasarkan data rekam medis pasien.

Populasi penelitian pada penelitian ini adalah seluruh kasus kematian dengan temuan cedera kepala di Rumah Sakit Umum Pusat Dr. M. Djamil padang Periode Januari 2018 sampai Desember 2019. Pemilihan besar sampel menggunakan metode Total Sampling. Sampel penelitian ini pasien meninggal dengan temuan cedera kepala di Rumah Sakit Umum Pusat Dr. M. Djamil padang Periode Januari 2018 sampai Desember 2019.

Pengambilan data dilakukan di RSUP dr M. Djamil Padang dengan cara mendata rekam medik kasus kematian dengan temuan cedera kepala yang memenuhi kriteria inklusi dan eksklusi. Data yang dicatat yaitu umur, jenis kelamin, pekerjaan, etiologi yang mendasari, lokasi kematian dan jenis luka. Pengolahan data dilakukan secara manual yaitu data yang dibutuhkan dicatat dan dicari persentasenya kemudian ditampilkan dalam bentuk tabel distribusi frekuensi.
Hasil

Berdasarkan hasil penelitian tentang karakteristik kasus kematian dengan temuan cedera kepala di Rumah Sakit Umum Pusat Dr. M. Djamil Padang periode Januari 2018 - Desember 2019 didapatkan 143 sampel kasus kematian dengan temuan cedera kepala yang terdaftar di bagian Forensik di RSUP DR. M. Djamil Padang, setelah dilakukan penelitian, didapatkan 121 orang yang telah memenuhi syarat kriteria inklusi penelitian, dan 22 orang yang tergolong kedalam kriteria eksklusi karena memiliki data rekam medik yang tidak lengkap berdasarkan jenis kelamin, pekerjaan, penyebab cedera kepala, lokasi kematian dan jenis luka.

\section{Jumlah Kasus Kematian dengan Temuan Cedera Kepala di RSUP Dr. M. Djamil Padang Periode Januari 2018 - Desember 2019 Berdasarkan Jenis Kelamin}

Tabel 1. Distribusi Jumlah Kasus Kematian dengan Temuan Cedera Kepala di RSUP Dr. M. Djamil Padang Periode Januari 2018 - Desember 2019 Berdasarkan Jenis Kelamin

\begin{tabular}{ccc}
\hline Jenis Kelamin & Frekuensi & \% \\
\hline Laki Laki & 88 & 72,7 \\
Perempuan & 33 & 27,3 \\
\hline Total & 121 & 100 \\
\hline
\end{tabular}

Hasil penelitian menunjukan jumlah kasus kematian dengan temuan cedera kepala terbanyak terjadi pada korban berjenis kelamin laki - laki yaitu sebanyak 88 kasus $(72,7 \%)$.

\section{Jumlah Kasus Kematian dengan Temuan Cedera Kepala di RSUP Dr. M. Djamil Padang Periode Januari 2018 - Desember 2019 Berdasarkan Usia}

Tabel 2. Distribusi Jumlah Kasus Kematian dengan Temuan Cedera Kepala di RSUP Dr. M. Djamil Padang Periode Januari 2018 - Desember 2019 Berdasarkan Usia

\begin{tabular}{ccc}
\hline Usia & Frekuensi & $\mathbf{\%}$ \\
\hline 0-17 Tahun & 33 & 27,3 \\
18-65 Tahun & 76 & 62,8 \\
66 - 79 Tahun & 11 & 9,1 \\
80 - 99 Tahun & 1 & 0,8 \\
\hline Total & 122 & 100 \\
\hline
\end{tabular}

Jumlah kasus kematian dengan temuan cedera kepala terbanyak terjadi pada kelompok usia 18 65 tahun dengan jumlah 76 kasus $(62,8 \%)$. 
3. Jumlah Kasus Kematian dengan Temuan Cedera Kepala di RSUP Dr. M. Djamil Padang Periode Januari 2018 - Desember 2019 Berdasarkan Pekerjaan

Tabel 3. Distribusi Jumlah Kasus Kematian dengan Temuan Cedera Kepala di RSUP Dr. M. Djamil Padang Periode Januari 2018 - Desember 2019 Berdasarkan Pekerjaan

\begin{tabular}{lcc}
\hline \multicolumn{1}{c}{ Pekerjaan } & Frekuensi & \% \\
\hline Pelajar & 29 & 23,9 \\
Mahasiswa & 3 & 2,5 \\
Pegawai Swasta & 8 & 6,6 \\
Wiraswasta & 15 & 12,4 \\
Pensiunan & 1 & 0,8 \\
PNS & 8 & 6,6 \\
Petani & 11 & 9,1 \\
Nelayan & 2 & 1,7 \\
Buruh & 8 & 6,6 \\
TNI/Polri & 2 & 1,7 \\
IRT & 19 & 15,7 \\
Tidak Bekerja & 15 & 12,4 \\
\hline \multicolumn{1}{c}{ Total } & 121 & 100 \\
\hline
\end{tabular}

Jumlah kasus kematian dengan temuan cedera kepala terbanyak terjadi pada korban dengan kategori pekerjaan pelajar yaitu sebesar 29 kasus (23.9\%).

\section{Jumlah Kasus Kematian dengan Temuan} Cedera Kepala di RSUP Dr. M. Djamil Padang Periode Januari 2018 - Desember 2019 Berdasarkan Penyebab Cedera Kepala

Tabel 4. Distribusi Jumlah Kasus Kematian dengan Temuan Cedera Kepala di RSUP Dr. M. Djamil Padang Periode Januari 2018 - Desember 2019 Berdasarkan Penyebab Cedera Kepala

\begin{tabular}{ccc}
\hline Penyebab Cedera Kepala & Frekuensi & \% \\
\hline Kecelakaan Lalu lintas & 107 & 88,5 \\
Jatuh Dari Ketinggian & 10 & 8,2 \\
Penyerangan & 1 & 0,83 \\
Kecelakaan Kerja & 3 & 2,5 \\
\hline \multicolumn{1}{c}{ Total } & 121 & 100 \\
\hline
\end{tabular}

Jumlah kasus kematian dengan temuan cedera kepala terbanyak terjadi pada korban dengan penyebab cedera kepala kecelakaan lalu lintas yaitu sebesar 107 (88,5\%).

5. Jumlah kasus kematian dengan temuan cedera kepala di RSUP Dr. M. Djamil padang periode Januari 2018 - Desember 2019 berdasarkan lokasi kematian
Tabel 5. Distribusi Jumlah Kasus Kematian dengan Temuan Cedera Kepala di RSUP Dr. M. Djamil Padang Periode Januari 2018 - Desember 2019 Berdasarkan Lokasi Kematian dan Jenis Luka

\begin{tabular}{lcc}
\hline \multicolumn{1}{c}{ Variabel } & Frekuensi & \% \\
\hline Lokasi Kematian & & \\
Meninggal di RS & 108 & 89,3 \\
Meninggal di TKP & 10 & 8,2 \\
Meninggal di Perjalanan & 3 & 2,5 \\
Jenis Luka & & \\
Robek & 68 & 56,2 \\
Lecet & 109 & 90,1 \\
Memar & 89 & 73,5 \\
Patah & 44 & 36,4 \\
\hline Total & 121 & 100 \\
\hline
\end{tabular}

Jumlah kasus kematian dengan temuan cedera kepala, kematian terbanyak terjadi di rumah sakit yaitu sebesar 108 (89,3\%). Jenis luka yang paling banyak ditemukan pada kasus kematian dengan temuan cedera kepala adalah luka lecet dengan 109 kasus $(90,1 \%)$.

\section{Pembahasan}

Cedera kepala masih menjadi penyebab utama morbiditas dan mortalitas pada populasi dunia berumur dibawah 45 tahun. Tujuan dari penelitian ini adalah untuk mengetahui karakteristik dari kasus kematian dengan temuan cedera kepala. Dari hasil penelitian yang dilakukan di Bagian Forensik RSUP Dr. M. Djamil Padang pada Maret 2020 hingga Juni 2020 didapatkan jumlah kasus kematian dengan temuan cedera kepala di RSUP Dr. M Djamil Padang tahun 2018-2019 didapatkan 121 orang yang memenuhi kriteria inklusi dan tidak memenuhi kriteria eksklusi.

Angka kejadian kematian dengan temuan cedera kepala lebih tinggi pada jenis kelamin lakilaki dibanding perempuan. Jenis kelamin pasien meninggal dengan temuan cedera kepala didominasi oleh laki-laki sebanyak 88 orang $(72,7 \%)$, sedangkan perempuan sebanyak 33 orang $(27,3 \%)$. Hal ini sesuai dengan penelitian yang dilakukan oleh Made B.P (2019) yang menyatakan bahwa angka kejadian cedera kepala di RSUD Umbu Rara Meha di NTT di dominasi dengan laki laki dengan (67,7\%) dibandingkan perempuan. ${ }^{9}$ Hal ini juga di perkuat dengan penelitian yang dilakukan di Black Lion Specialized Hospital di Ethiopia pada Oktober hingga Agustus 2015 terdapat 390 pasien datang dengan cedera kepala,dengan rincian 335 pria $(85,9 \%)$ dan 55 wanita $(14,1 \%)^{2}$ Selain itu 
menurut penelitian yang dilakukan oleh Riskesdas (2013) menyatakan bahwa angka kejadian cedera kepala di dominasi oleh jenis kelamin laki-laki (55,4\%) dibandingkan perempuan, hal ini disebabkan oleh mobilitas yang tinggi di kalangan usia produktif.

Sophie Peeter et al melakukan penelitian mengenai cedera kepala di Kamboja pada tahun 2013 hingga 2016 dan didapatkan bahwa angka kejadian tertinggi terdapat pada rentang usia 21 hingga 60 tahun yaitu sebanyak 755 kasus $(78,4 \%),{ }^{10}$ Hal ini sejalan dengan data yang di dapatkan pada penelitian (Tabel 4.2) menunjukan bahwa kelompok usia 18 - 65 tahun dengan jumlah 76 kasus (62,8\%). mempunyai angka kejadian tertinggi kematian dengan temuan cedera kepala. Hasil ini juga di dukung dengan penelitian yang dilakukan di eropa dengan temuan (55\%) pasien berusia 0-44 tahun, dan (29\%) berusia 65 tahun atau lebih. ${ }^{11}$ Hasil ini juga di dukung oleh penelitian yang dilakukan oleh Yutaka, Toshikazu, Kiyotaka, et al yang menyatakan bahwa karakteristik pasien dengan trauma kepala rata rata berusia 21,4 hingga 51,4 tahun. $^{12}$

Ditinjau dari distribusi kasus berdasarkan pekerjaan di dapatkan bahwa kasus kematian dengan trauma cedera kepala terbanyak terdapat pada kategori pekerjaan pelajar dengan jumlah 29 kasus $(23,9 \%)$. Hasil penelitian ini sesuai dengan penelitian yang dilakukan oleh Azwar (2011) di RSU dr. Soedarso Pontianak bahwa kategori pekerjaan terbanyak di dominasi oleh pelajar dan diikuti oleh kategori pekerja lainnya, hal ini disebabkan oleh karna usia produktif terutama memiliki aktivitas yang terpusat di luar rumah dan memiliki mobilitas yang tinggi yaitu pada saat pergi dan pulang dari sekolah atau tempat kerja. Kegiatan- kegiatan diluar rumah tersebut, menyebabkan mereka memiliki resiko lebih tinggi untuk mengalami cedera kepala. ${ }^{13} \mathrm{Hal}$ ini juga di dukung oleh penelitian yang dilakukan di RSUP Haji Adam Malik Medan di tahun 2017 yang menyatakan bahwa penderita cedera kepala terbanyak berada di kategori pekerjaan pelajar / mahasiswa $(35,3 \%){ }^{14}$

Jenis terbanyak penyebab cedera kepala pada penelitian ini adalah kecelakaan lalu lintas yaitu sebesar 107 (88,4\%), hasil ini sesuai dengan penelitian yang dilakukan di di RSUP Haji Adam Malik Medan di tahun 2017 yang menyatakan bahwa penyebab terjadinya cedera kepala terbanyak adalah kecelakaan lalulintas (83,7\%). ${ }^{14}$ hal ini juga berkaitan dengan dengan kemajuan suatu negara. Pada negara berkembang penyebab utama cedera kepala adalah kecelakaan kendaraan bermotor $(42,4 \%){ }^{3}$ Hal serupa juga disebutkan dalam penelitian oleh Puvanachandra dan Hayder (2009), menemukan 60\% dari cedera kepala di Asia diakibatkan oleh kecelakaan lalu lintas. Peningkatan jumlah kendaraan bermotor akan mengakibatkan bertambahnya kepadatan kendaraan bermotor di jalanan. Peningkatan kepadatan ini disertai juga dengan ketidakpatuhan masyarakat terhadap peraturan dan rambu-rambu lalu lintas, menggunakan kecepatan yang sangat tinggi, kondisi jalan yang buruk, mabuk, kelelahan ataupun mengantuk saat mengendarai kendaraan bermotor, sehingga risiko terjadinya kecelakaan lalu lintas akan semakin meningkat. ${ }^{15}$

Lokasi kematian dengan temuan cedera kepala terbanyak pada penelitian ini didapatkan yaitu dirumah sakit dengan 108 kasus (89,3\%), diikuti dengan lokasi kematian di perjalanan sebanyak 10 kasus $(8,2 \%)$, dan di tempat terjadinya cedera sebanyak 3 kasus (2,5\%). Hal ini berkaitan erat dengan prehospital stage, Menurut Wibowo (2016) Terdapat 3 faktor utama di prehospital stage yang berperan terhadap kualitas hidup penderita nantinya, yaitu: Penolong pertama, Lama penanganan pertama, Alat transportasi pasien. ${ }^{16}$ Hal ini juga di dukung oleh Wadgure (2013) untuk meminimalisir masalah atau kejadian yang tidak diinginkan harus sesuai dengan standar prosedur salah satunya yaitu dari segi penolong. Penolong yakni perawat yang memiliki postur tubuh yang sama dan mempunyai tenaga agar tubuh pasien tetap sejajar dan tubuh pasien dapat dipindahkan tanpa adanya masalah. Peran perawat dalam hal transportasi pasien sangat besar. ${ }^{17}$ Kenyataannya berbeda di lapangan bahwa transportasi pasien menuju rumah sakit sebagian besar dilakukan oleh orang awam yang tidak terlatih dan mengantar pasien dengan transportasi publik atau kendaraan pribadi sehingga apabila terjadi masalah pada pasien cedera kepala berat selama transportasi maka orang awam yang belum terlatih tidak dapat mengatasi masalah tersebut dan dapat menimbulkan cedera kepala sekunder serta dapat menimbulkan kematian pada pasien dengan 
cedera kepala berat. ${ }^{16}$ Studi yang di lakukan oleh Taylor dalam Chard \& Makary (2015), menjelaskan bahwa transportasi dapat menimbulkan cedera kepala sekunder jika selama proses transportasi pasien cedera kepala tidak dilakukan penanganan. Cedera kepala sekunder dapat terjadi selama transportasi salah satunya adalah hipotensi dan hipoksia. Hipoksia merupakan faktor prediktor terhadap outcome yang buruk pada pasien yang mengalami cedera kepala berat sebagai akibat dari risiko tambahan cedera kepala sekunder yang di alami oleh pasien, hipoksia yang tercatat sebanyak $27-55 \%$ dapat berasal dari tempat kejadian di dalam ambulan/saat transportasi atau pada saat kedatangan di instalasi gawat darurat. ${ }^{17}$

Jenis luka yang paling banyak ditemukan pada kasus kematian dengan temuan cedera kepala adalah luka lecet dengan 109 kasus $(90,1 \%)$. Hal ini sesuai dengan penelitian tentang korban kecelakaan lalu lintas yang masuk di RSU PROF. Dr. R.D. Kandou Manado pada tahun 2012 yang menyatakan bahwa jenis luka yang paling banyak ditemukan pada kasus tersebut adalah luka lecet dengan presentase 49,57\%.48 Luka lecet paling banyak ditemukan pada kasus kematian dengan temuan cedera kepala terutama pada korban kecelakaan lalu lintas hal ini disebabkan karena pada saat korban terjatuh ke aspal, biasanya korban akan terseret akibat gaya tolak, gesekan antara aspal, baju, dan kulit sehingga akan menghasilkan luka lecet pada bagian tubuh yang berkontak langsung. ${ }^{49}$

\section{Simpulan}

Total sampel penelitian didapatkan 121 sampel orang meninggal dengan temuan cedera kepala yang terdaftar di bagian Forensik di RSUP DR. M. Djamil Padang. Mayoritas kasus kematian dengan temuan cedera kepala terjadi pada jenis kelamin laki-laki. Kelompok usia terbanyak pada kasus kematian dengan temuan cedera kepala ada lah usia dewasa (18-65 tahun).

Kategori pekerjaan dengan temuan kasus terbanyak adalah kategori pelajar dengan jumlah. Penyebab cedera kepala terbanyak dalam kasus kematian dengan temuan cedera kepala terjadi pada korban dengan penyebab cedera kepala kecelakaan lalu lintas, Jenis luka yang paling banyak di temui adalah luka lecet.

\section{Ucapan Terima Kasih}

Ucapan terimakasih diberikan kepada pihak Rumah Sakit DR. M Djamil Padang yang tlah memberikan izin untuk melakukan penelitian ini.

\section{Daftar Pustaka}

1. Safrizal, Syaiful H, Bachtiar H. Hubungan nilai oxygen delivery dengan outcome rawatan pasien cedera kepala sedang. Japardi. 2013.p. 1-3.

2. Profile of Head Injuries: Prehospital Care, Diagnosis, and Severity in an Ethiopian Tertiary Hospital Tsegazeab Laeke. World Neurosurg. 2019. 127:186192

3. Li M, Zhao Z, Yu G, Zhang J. Epidemiology of Traumatic Brain Injuryoverthe World: A Systematic Review. Austin Neurology \& Neurosciences. 2016;1(2):1007-1020

4. Irawan H, Setiawan F, Dewi, Dewanto D. Perbandingan Glasgow Coma Scale dan Revised Trauma Score dalam Memprediksi Disabilitas Pasien Trauma Kepala di Rumah Sakit Atma Jaya. Madjalah Kedokteran Indonesia. 2010;60(10).

5. Kemenkes Ri. Riset Kesehatan Dasar; RISKESDAS. Jakarta: BalitbangKemenkes Ri. 2013.

6. Roozenbeek B, Maas AIR, Menon DK. Changing patterns in the epidemiology of traumatic brain injury. Nat Rev Neurol. 2013;9:231- 236.

7. Irianto K. Anatomi dan Fisiologi. Bandung; Alfabeta, 2012; p. 330-46

8. Frieden, T. R., Houry, D., Baldwin, G. Traumatic brain injury in the United States: Epidemiology and rehabilitation. CDC and NIH Report to Congress. 2015.p. 1-74.

9. Putra M.B. Karakteristik pasien cedera kepala di Rumah Sakit Umum Daerah (RSUD) Umbu Rara Meha Waingapu periode 1 Januari 2017 - 31 Desember 2018. Universitas Nusa Cendana. 2019.

10. Sophie P, Caitlin B, Iv V, Sam N, Din V, Kee B, et al. Epidemiology of Traumatic Brain Injuries at a Major Government Hospital in Cambodia. Intisari Sains Medis. 2019:10(2):511-515.

11. Majdan M, Plancikova D, Brazinova A, Rusnak M, Nieboer D, Feigin V, et al. Epidemiology of traumatic brain injuries in Europe: a crosssectional analysis. Lancet Public Health. 2016;1:7683.

12. Yutaka, Toshikazu K, Kiyotaka A, Yasuharu K, Francis T, C.E and Ichiro K. Revised Trauma Scoring system to predict in-hospital mortality in the emergency department: Glasgow coma scale, age, and systolic blood pressure score. NBNC. 2011:15(191), 4-5

13. Muhammad A. Gambaran cedera kepala dengan komplikasi perdarahan epiduran di RSU dokter soedarso Pontianak 1 Januari - 31 Desember 2010. [Skripsi]. Pontianak: Fakultas Kedokteran Universitas Tanjungpura; 2011.

14. Muhammad A. Gambaran cedera kepala dengan komplikasi perdarahan epiduran di RSU dokter soedarso Pontianak 1 Januari - 31 Desember 2010. [Skripsi]. Pontianak: Fakultas Kedokteran Universitas Tanjungpura; 2011.

15. Elisabeth Y. Karakteristik Cedera Kepala di Rumah Sakit Umum Pusat Haji Adam Malik Medan Tahun 2016-2017 Sigalingging, Medan: Fakultas Kedokteran Universitas Sumatra Utara; 2017. 
16. Sarangi.L, P. P. Study on Epidemiological factors associated with road traffic accidents presenting to the casualty of a private hospital in Bhubaneswar. Journal of Community Medicine,2009:5 (2),1-10. 